Oura transboundary complex between Cameroon and Chad. Ministers asked to include the Central African Republic in the accord, subject to follow-up tripartite meetings in Ndjamena in September and November 2012 in which an agreement on anti-poaching transboundary collaboration was prepared. In June 2012 the ministers in charge of wildlife of the COMIFAC member states also adopted the Central African Wildlife Trade Law Enforcement Action Plan (CAWTLEAP, 2012-2017). News as at February 2013 is that, recognizing the increasingly military character of effective anti-poaching, the dialogue amongst the three ministers in charge of wildlife is to be widened to include their colleagues in charge of defence.

Important first steps have been taken with this longawaited tri-national dialogue and signing of CAWTLEAP but more is needed. The dramatic increase in elephant poaching has been triggered by the rapidly increasing demand for ivory in China, Thailand and other East Asian countries. Regional and intercontinental dialogue, including ivory consumer and transit countries, was called for by a platform meeting organized jointly by the US Embassy and the Governments of Gabon and Central African Republic in Libreville in April 2012. The greatest challenge now is to translate these dialogues into concrete collaboration. This may be boosted by treating the illegal international wildlife trade as a crime that mobilizes action beyond ministries in charge of wildlife protection. As called for by CAWTLEAP, national units to combat wildlife crime are being established, comprising law enforcement agencies (Defence, Justice, Customs, Police, Wildlife, Interior and Exterior) and assisted by technical partners such as INTERPOL, conservation organizations and diplomatic missions. These units are being tasked to bundle resources and intelligence systems to track, arrest and prosecute wildlife criminals to the full extent of the law.

This attention to large-scale transboundary poaching should not, however, divert attention from increasingly commercial small-scale poaching operations, with implication of powerful elites, for which collaboration with local communities should, whenever possible, be reinforced. Only reacting to these different types of poaching will ensure that elephants and other wildlife do not follow the same fate as the western black rhino, extinct a decade ago.

PAUL SCHOLTE GIZ-COMIFAC support programme, Yaounde, Cameroon.E-mail paul.scholte@giz.de

Chouatbou NChoutpouen Executive Secretariat COMIFAC, Yaounde, Cameroon

BAS HUIJBREGTS WWF-CARPO, Yaounde, Cameroon

\section{A new market-based tool for conservation: improving aquaculture through ASC certification}

Almost half of all seafood comes from aquaculture farms and by 2018 more seafood will be farmed than caught from the wild. Reconciling food security with the protection of aquatic and marine ecosystems is a major conservation challenge. Solutions need to address both the demand of an increasing global population as well as the market forces that supply that demand.

In August 2012 the first seafood bearing the Aquaculture Stewardship Council's (ASC) 'responsibly farmed' logo entered the market place. The ASC logo is complimentary to the Marine Stewardship Council's label for sustainablycaught wild fish. The ASC represents the latest major certification initiated by WWF's Markets Transformation Initiative, which uses market forces for conservation benefits across commodities, including forests (Forest Stewardship Council), soya (the Roundtable for Responsible Soy), sugar (Bonsucro), cotton (Better Cotton), palm oil (Roundtable on Sustainable Palm Oil) and freshwater (Alliance for Water Stewardship).

The ASC logo encompasses a series of standards for major farmed species and was developed through an international, multi-stakeholder process involving c. 2,000 experts globally over 8 years. As with other environmental certification schemes of this magnitude, a commitment to ongoing development and improvement of the standards is critical. The ASC standards contain performance indicators (metrics) designed to improve the viability of threatened and protected species, essential habitat, freshwater quantity and quality, carbon and greenhouse gas emissions, and the management of wild fisheries and terrestrial crops used in feed. These measures, as well as social considerations, are formally assessed by teams of independent experts, led by accredited auditors with the technical background to evaluate impacts. Producers are required by the team to improve practices to meet conditions for certification. Auditor manuals contain specific instructions and methods with actionable and measurable steps for producers to implement best practices. Standards also have meaningful data-reporting requirements that will increase global knowledge of aquaculture, and some standards ask producers to initiate area-based management plans to address cumulative impacts. Increased market access, profits and indirect benefits (e.g. public recognition, funding, increased harmony with surrounding communities) are all powerful incentives for those interested in demonstrating commitment to responsible production.

At present, ASC-labelled Tilapia and Pangasius are available to consumers, with further categories that include salmon, bivalves, abalone, freshwater trout, shrimp, Seriola and cobia to emerge over the next year. In the past 3 months 
leading producers have partnered with auditors in independent certification bodies to field test the standards for salmon, bivalves and abalone, which will move into full use shortly.

Researchers, NGO staff and others should be aware that transparency and stakeholder participation is an integral part of the ASC process. There will be opportunities to influence environmental and social change in regions throughout the world by engaging in ASC assessments. The name and location of farms undertaking assessment will be posted on the ASC website (http://www.asc-aqua. org) 1 month prior to on-site audits, along with the names of proposed team members. Those interested in contributing to assessments for particular farms should contact the certification body responsible for a given assessment directly. Comments or concerns (including team composition) raised by members of both the public and private sectors will be incorporated into decisions made by assessment teams and audit reports will be publicly available via the ASC website.

SiÂN Morgan and SABINE DAUmE Scientific Certification Systems, 2000 Powell Street, Emeryville, California 95061, USA.

E-mailsmorgan@scscertified.com

Hank Cauley Paul G. Allen Family Foundation, Seattle, Washington, USA

CHRIS NINNES Aquaculture Stewardship Council, Utrecht, Netherlands

JoSE VILLALON Nutreco, Amersfoort, Netherlands

\section{American Association of Zoo Keepers: bowling for rhinos}

When black rhino Diceros biconrnis populations plummeted in the 1980s because of poaching, zoo keepers throughout North America took action to raise funds for conservation of the species: thus the Bowling For Rhinos fund-raiser began. At the same time as they spread the word about the plight of the black rhino, zoo keepers organized annual fund-raisers to secure money from the public to conserve rhinos in the wild. Since 1990 the American Association of Zoo keepers (AAZK) has sponsored Bowling For Rhinos, which has now raised over USD 4.3 million for conservation. Over 70 AAZK chapters participate throughout the USA and Canada, raising more than USD 300,000 annually. The funds are sent through Lewa USA, the International Rhino Foundation, and Action for Cheetahs in Kenya. The Association is currently developing a new campaign, in Australia. The funds raised by Bowling For Rhinos supports Lewa Wildlife Conservancy (formerly Ngare Sergoi rhino sanctuary) in Kenya, Ujung Kulon National Park in Java, Indonesia, Bukit Barisan Selatan National Park and Way Kambas in Sumatra, and Manas National Park in India. As well as contributing to saving all five rhino species, the funding helps secure organisms ranging in size from orchids to elephants. Conservation of rhino habitat is also helping to conserve the Endangered Grevy's zebra and the Critically Endangered hirola. The Bowling For Rhinos fund-raiser is now preparing for its 24th year. The programme is run entirely by volunteers, enabling $100 \%$ of all donations to go directly to conservation in the field. For more information please see http://aazkbfr.org

Patty Pearthree American Association of Zoo KeepersBowling For Rhinos, 318 Montibello Drive, Cary, NC 27513, USA.E-mail ppear3@pear3.org 